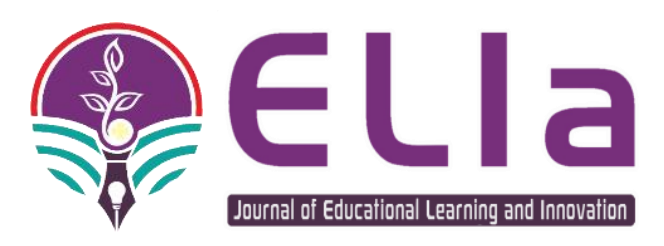

Journal of

Educational Learning and Innovation

p-ISSN:2775-2623 and e-ISSN: 2775-2739

Volume 1 Number 2 September 2021, Halaman 129-145

DOI: $10.46229 /$ elia.v1i2

\title{
PEMBELAJARAN SEKOLAH INDONESIA LUAR NEGERI DI TENGAH PANDEMI COVID-19 DI SEKOLAH INDONESIA KUALA LUMPUR (SIKL) DAN SEKOLAH INDONESIA DEN HAAG (SIDH)
}

\author{
Siti Nur Khoriah ${ }^{1}$, Nanda Melina Rizkia ${ }^{2}$, Annisa Fajriatul Awwaliyah ${ }^{3}$, Annisa Dita \\ Ramadhani $^{4}$, Ahmad Miftahul Umam ${ }^{5}$, Husni Mubarok ${ }^{6}$ \\ 1,2,3,4,5,6 Program Studi Pendidikan Guru Madrasah Ibtidaiyyah (PGMI) \\ Institut Agama Islam Negeri Kudus, Indonesia \\ Email: sitinurkhriah361@gmail.com ${ }^{1}$, nandamely21@ gmail.com² \\ safadenisa@gmail.com ${ }^{3}$, annisaditaramadhani05@gmail.com ${ }^{4}$, \\ miftahulumam025@gmail.com ${ }^{5}$ husnimubarok@iainkudus.ac.id ${ }^{6}$
}

(Received: 28 Desember 2020; Reviewed: 4 Agustus 2021; Accepted: 10 September 2021; Available online: September-2021; Published: September-2021)

(c) This is an open access article distributed under the Creative Commons
Attribution License
Attribution 4.0 International (CC BY 4.0) (https://creativecommons.org/licenses/by/4.0/)

\begin{abstract}
ARTIKEL INFO
Kata Kunci:

Pandemi Covid-19, Pembelajaran, Sekolah Indonesia Den Haag (SIDH), Sekolah Indonesia Kuala Lumpur (SIKL).
\end{abstract}

\begin{abstract}
Abstrak. Pandemi Covid-19 telah membawa dampak yang cukup besar dalam berbagai bidang seperti bidang pendidikan, bidang perekonomian, bidang industri, bidang pertahanan, bidang politik dan lain sebagainya. Dalam bidang pendidikan proses pembelajaran yang biasanya dilakukan di Sekolah dipindah tempatkan di rumah masing-masing. Maka diperlukan solusi untuk menjawab permasalahan tersebut. Pembelajaran secara daring adalah salah satu alternatif yang dapat mengatasi masalah tersebut. Tujuan penelitian ini adalah untuk memperoleh gambaran pelaksanaan pembelajaran daring di Sekolah Indonesia Luar Negeri Kuala Lumpur, Malaysia (SIKL) dan Sekolah Indonesia Den Haag, Belanda (SIDH) sebagai upaya menekan penyebaran covid-19 di Sekolah. Subjek penelitian adalah siswa dan guru disekolah tersebut. Data dikumpulkan dengan wawancara Seminar Nasional Program Studi PGMI IAIN Kudus pada tahun 2020 melalui zoom cloud meeting. Metode yang digunakan dalam penelitian ini adalah Metode Analisis Kualitatif deskriptif. Hasil penelitian menunjukkan bahwa: (1) Siswa telah memiliki fasilitas-fasilitas dasar yang dibutuhkan untuk mengikuti pembelajaran daring; (2) pembelajaran daring memiliki fleksibilitas dalam pelaksanaannya dan mampu mendorong munculnya kemandirian belajar dan motivasi untuk lebih aktif dalam belajar; dan (3) pembelajaran jarak jauh mendorong munculnya perilaku social distancing dan meminimalisir munculnya keramaian siswa sehingga dianggap dapat mengurangi potensi penyebaran Covid-19 di lingkungan sekolah. Lemahnya pengawasan terhadap siswa, kurang kuatnya sinyal di daerah pelosok, dan mahalnya biaya kuota adalah tantangan tersendiri dalam pembelajaran daring.
\end{abstract}


2021 | Khoriah, S.N., Rizkia, N.M., Awwaliyah, A.F., Ramadhani, A.D., Umam, A.M., Mubarok, H., Pembelajaran Sekolah Indonesia Luar Negeri di Tengah Pandemi Covid-19 di Sekolah Indonesia Kuala Lumpur (SIKL) dan Sekolah Indonesia Den Haag (SIDH)

\begin{abstract}
The Covid-19 pandemic has had a considerable impact in various fields such as education, the economy, industry, defense, politics and so on. In the field of education, the learning process that is usually carried out in schools is transferred to their respective homes. So a solution is needed to answer these problems. Online learning is an alternative that can solve this problem. The purpose of this study was to obtain an overview of the implementation of online learning at the Indonesian Foreign School Kuala Lumpur, Malaysia (SIKL) and the Indonesian School in The Hague, Netherlands (SIDH) as an effort to suppress the spread of covid-19 in schools. Research subjects are students and teachers at the school. Data were collected by interviewing the National Seminar of the IAIN Kudus PGMI study program in 2020 through zoom cloud meetings. The method used in this research is descriptive qualitative analysis method. The results showed that: (1) Students already have the basic facilities needed to take part in online learning; (2) online learning has flexibility in its implementation and is able to encourage independent learning and motivation to be more active in learning; and (3) distance learning encourages the emergence of social distancing behavior and minimizes the appearance of student crowds so that it is considered to reduce the potential for the spread of Covid-19 in the school environment. Weak supervision of students, lack of strong signals in remote areas, and high quota fees are challenges in online learning.
\end{abstract}

\section{PENDAHULUAN}

Sekolah Indonesia Luar Negeri
(SILN) merupakan sekolah yang
didirikan di luar negeri yang
diperuntukkan untuk anak-anak

Indonesia yang tinggal di luar negeri. SILN merupakan sekolah yang berstatus swasta dengan berbantuan, dimana penyelenggara dan pengelolanya menjadi tanggung jawab bersama. Bantuan yang diberikan oleh pemerintah Indonesia kepada SILN melalui kementrian pendidikan nasional dapat berupa sarana maupun prasarana seperti, buku- buku pelajaran, pengiriman Pegawai Negeri Sipil (PNS) yang ditugaskan mengajar, baik sebagai kepala sekolah maupun sebagai guru dan staff. Peran SILN tidak jauh berbeda dengan sekolah- sekolah yang ada di Indonesia, yaitu untuk mencerdaskan kehidupan bangsa. Kurikulum yang diterapkan di SILN juga sama seperti kurikulum yang dirterapkan di Indonesia yaitu kurikulum 2013 (K13). Sesuai pula dengan tujuan pendidikan nasional yang tercantun dalam Undang-undang No. 20 tahun 2003 tentang sistem pendidikan nasional pasal 3 yang berbunyi, tujuan pendidikan nasional Indonesia adalah mengembangkan potensi peserta didik agar menjadi manusia yang beriman dan bertaqwa kepada Tuhan yang Maha Esa, berakhlak mulia, sehat, berilmu, cakap, kreatif, mandiri, dan menjadi warga Negara yang demokratis serta 
2021 | Khoriah, S.N., Rizkia, N.M., Awwaliyah, A.F., Ramadhani, A.D., Umam, A.M., Mubarok, H., Pembelajaran Sekolah Indonesia Luar Negeri di Tengah Pandemi Covid-19 di Sekolah Indonesia Kuala Lumpur (SIKL) dan Sekolah Indonesia Den Haag (SIDH)

bertanggung jawab. Yang membedakan antara SILN dengan sekolah yang ada di Indonesia adalah letak tempatnya yakni berada di luar negeri dan dalam negeri.

Menurut kompas, pada 28 Maret

2020 pandemi covid-19 membawa dampak diberbagai bidang seperti bidang pendidikan, bidang perekonomian, bidang industri, bidang pertahanan, bidang politik dan lain sebagainya. Dalam bidang pendidikan proses pembelajaran yang biasanya dilakukan di Sekolah dipindah tempatkan di rumah masing-masing.

Pemerintah mengeluarkan surat edaran (SE) pada tanggal 18 Maret 2020 yaitu: Segala kegiatan yang dilakukan di dalam maupun di luar ruangan pada semua sektor untuk sementara waktu di tunda untuk mengurangi penyebaran wabah covid-19 terutama dalam bidang pendidikan. Menteri pendidikan dan kebudayaan republik indonesia (Kemendikbud) pada tanggal 24 Maret 2020 mengeluarkan surat edaran Nomor 4 Tahun 2020 tentang pelaksanaan kebijakan pendidikan dalam masa darurat penyebaran covid-19, pada surat edaran tersebut dijelaskan mengenai proses pembelajaran yang dilaksanakan di rumah masing-masing melalui pembelajaran secara daring atau jarak jauh dengan tujuan memberikan pengalaman belajar yang bermakna bagi peserta didik. Pembelajaran yang dilakukan secara daring diterapkan sebagai upaya untuk mencegah meluasnya penyebaran covid-19, (Sumanto, Y., \& Sadewo, Y.D., 2021). Maka dari itu, dihimbau seluruh lembaga pendidikan untuk sementara waktu tidak melaksanakan aktivitas seperti biasanya karena hal tersebut dapat meminimalisir menyebarnya penyakit covid-19 tersebut. Selain itu, kebijakan lockdown atau karantina diberlakukan sebagai upaya untuk mengurangi terjadinya interaksi antar banyak orang yang dapat memberikan akses pada penyebaran virus corona.

Dengan adanya beberapa kebijakan diatas membuat pemerintah dan lembaga terkait harus menghadirkan alternatif-alternatif yang diterapkan dalam proses pendidikan bagi peserta didik. Kondisi ini membutuhkan guru Berinovasi dalam proses pembelajaran, terutama melalui pembelajaran online (dalam format Internet). Solusi yang dilakukan selama pandemi adalah dengan menggunakan Pembelajaran berbasis web. Guru dituntut berinovasi dalam penggunaan pembelajaran. Bentuk e-learning (berbasis e-learning) akan terus ada dan terus berkembang. Dengan pesatnya pertumbuhan kepemilikan 
2021 | Khoriah, S.N., Rizkia, N.M., Awwaliyah, A.F., Ramadhani, A.D., Umam, A.M., Mubarok, H., Pembelajaran Sekolah Indonesia Luar Negeri di Tengah Pandemi Covid-19 di Sekolah Indonesia Kuala Lumpur (SIKL) dan Sekolah Indonesia Den Haag (SIDH)

komputer di dunia, e-learning menjadi semakin banyak Pertumbuhan dan akses mudah. Kecepatan koneksi internet meningkat, Lebih banyak kesempatan untuk metode pelatihan multimedia muncul. Harapan untuk belajar model online akan menjadi solusi yang dapat membantu pembelajaran menengah Pandemi COVID-19.

Nakayama mengungkapkan bahwa dari semua literatur dalam elearning mengindikasikan bahwa tidak semua peserta didik dapat melaksanakan pembelajaran secara online dengan sukses. Hal tersebut dapat terjadi karena adanya faktor lingkungan belajar dan karakteristik peserta didik. (Nakayama M, Yamamoto H, 2007).

Di masa pandemi yang mewabah di dunia saat ini, membawa dampak yang besar bagi berbagai bidang, salah satunya yaitu bidang pendidikan. Hal tersebut terjadi bagi sekolah Indonesia di luar negeri. Sama halnya seperti di Indonesia, proses belajar mengajar yang biasanya dilakukan didalam kelas untuk menghindari penyebaran wabah covid19, proses pembelajaran dialihkan di rumah masing-masing dimana pembelajaran dilakukan secara daring (dalam jaringan) atau online. Banyak aplikasi yang dapat digunakan dalam melakukan proses pembelajaran secara daring, seperti, Google Classroom, Google Meet, Zoom Aplikasi, Youtube, E-Learning, Whatshapp, Edmodo dan lain sebagainya. Dalam melakukan pembelajaran secara daring, kreatifitas guru dalam menciptakan inovasi-inovasi baru kaitannya dengan pengggunaan strategi, metode, media dan perangkat pembelajaran lainnya sangat dibutuhkan untuk mengoptimalkan pembelajaran secara efektif dan efisien.

Ada beberapa sekolah Indonesia di luar negeri seperti Sekolah Indonesia Kuala Lumpur (SIKL), Sekolah Indonesia Nederland (SIN), Sekolah Indonesia Bangkok, Sekolah Indonesia Beograd, Sekolah Indonesia Cairo, Sekolah Indonesia Damaskus, Sekolah Indonesia Kota Kinabalu, Sekolah Indonesia Makkah, Sekolah Indonesia Moscow, Sekolah Indonesia Singapura, Sekolah Indonesia Tokyo, Sekolah Indonesia Riyadh (SIR), Sekolah Indonesia Jeddah (SIJ), Sekolah Indonesia Yangon, dan Sekolah Indonesia Davao.

Tujuan dari penelitian ini adalah untuk mendapatkan informasi penerapan pembelajaran Sekolah Indonesia Kuala Lumpur (SIKL) dan Sekolah Indonesia Nederland (SIN) di tengah pandemi covid-19. 
2021 | Khoriah, S.N., Rizkia, N.M., Awwaliyah, A.F., Ramadhani, A.D., Umam, A.M., Mubarok, H., Pembelajaran Sekolah Indonesia Luar Negeri di Tengah Pandemi Covid-19 di Sekolah Indonesia Kuala Lumpur (SIKL) dan Sekolah Indonesia Den Haag (SIDH)

\section{METODE}

Metode yang digunakan dalam penelitian ini adalah metode Kualitatif deskriptif. Dimana sebuah metode penelitian yang memanfaatkan data kualitatif dan dijabarkan secara deskriptif. Metode ini gabungan dari penelitian kualitatif dan deskriptif. Penelitian kualitatif merupakan penelitian tentang riset yang bersifat deskriptif dan cenderung menggunakan analisis. Menurut Sugiono (2010: 9), penelitian kualitatif adalah penelitian dimana peneliti ditempatkan sebagai instrumen kunci, teknik pengumpulan data dilakukan secara penggabungan dan analisis data bersifat induktif. Sedangkan penelitian deskriptif merupakan salah satu jenis penelitian yang tujuannya menyajikan gambaran lengkap mengenai setting sosial, dimaksudkan untuk eksplorasi dan klarifikasi mengenai suatu kenyataan sosial. Dengan menggunakan deskriptif-kualitatif, analisis data yang diperoleh berupa kata-kata, gambar, maupun perilaku dituangkan dalam bentuk paparan mengenai kondisi yang diteliti dalam bentuk uraian naratif (Margono, 2003). Menurut Nana Syaodih Sukmadinata (2011: 73), penelitian deskriptif kualitatif ditujukan untuk mendeskripsikan dan menggambarkan fenomena- fenomena yang ada, baik bersifat alamiah maupun rekayasa manusia, yang telah memperhatikan mengenai karakteristik, kualitas, keterkaitan antar kegiatan. Selain itu, penelitian deskriptif tidak memberikan perlakuan, manipulasi atau pengubahan pada variabel- variabel yang diteliti, melainkan menggambarkan suatu kondisi yang apa adanya.

Sesuai dengan permasalahan yang menjadi fokus dalam penelitian ini yaitu gambaran deskriptif mengenai pembelajaran sekolah Indonesia luar negeri di tengah pandemi covid-19 di Sekolah Indonesia Kuala Lumpur (SIKL) dan Sekolah Indonesia Den Haag (SIDH). Maka, peneliti menggunakan pendekatan kualitatif dengan mendeskripsikan data yang telah diperoleh dari hasil penelitian.

Memuat jenis penelitian, waktu dan tempat penelitian, target/sasaran, subjek penelitian, prosedur, instrumen dan teknik analisis data serta hal-hal lain yang hubungan dengan cara penelitian author. Mengunakan sub-subjudul pada bagian target/sasaran, subjek penelitian, prosedur, data dan instrumen, dan teknik pengumpulan data, serta teknik analisis data serta hal-hal lain yang berkait dengan cara penelitian dengan subsubheading. Sub-subjudul ditulis dengan huruf kapital pada awal huruf kata, 
2021 | Khoriah, S.N., Rizkia, N.M., Awwaliyah, A.F., Ramadhani, A.D., Umam, A.M., Mubarok, H., Pembelajaran Sekolah Indonesia Luar Negeri di Tengah Pandemi Covid-19 di Sekolah Indonesia Kuala Lumpur (SIKL) dan Sekolah Indonesia Den Haag (SIDH)

unbold TNR-11 dan tidak perlu diberi notasi.

\section{HASIL DAN PEMBAHASAN}

\section{Proses Pembelajaran Sekolah di Tengah Pandemi Covid-19}

Pandemi covid-19 membawa dampak yang sangat besar dalam berbagai kehidupan, seperti perekonomian, sosial, keamanan, politik, pendidikan, dan lain sebagainya. Pengaruh covid-19 dalam bidang pendidikan membawa pengaruh yang cukup besar, dimana pembelajaran yang biasanya dilakukan di sekolah atau madrasah dipindah tempatkan di rumah masing-masing guna mencegah penularan wabah covid-19. Peran teknologi dalam mengoptimalkan pembelajaran di masa pandemipun sangat penting untuk melakukan interaksi pembelajaran jarak jauh, sehingga di masa pandemi ini muncul istilah baru dalam bidang pendidikan yaitu pembelajarang daring (dalam jaringan) atau pembelajaran secara online. Selain itu, peran orang tua sangat penting dalam melakukan pendampingan bagi anak-anaknya yang melakukan proses pembelajaran di rumah.

Banyak aplikasi-aplikasi yang dapat digunakan dalam melakukan proses pembelajaran secara daring, seperti, Google Classroom, Google Meet, Zoom Aplikasi, Youtube, E-Learning, Whatshapp, Edmodo dan lain sebagainya. aplikasi sebagai mesin pencari ,aplikasi sebagai sarana bertemu dan bertatap muka secara langsung,aplikasi YouTube sebagai hasil dari output kerja siswa saat mengerjakan sesuatu, aplikasi WhatsApp dan edmodo fasilitasi agar mudah antara guru dan siswa berkomunikasi. Menurut pendapat Molinda (2005), yang dikutip oleh Arizona (2020:66), pembelajaran online merupakan bentuk pembelajaran atau pelatihan jarak jauh dengan memanfaatkan teknologi telekomunikasi dan informasi, misalnya internet.beruntungnya internet saat ini sudah masuk di berbagai daerah dan koneksinya sudah lancar dan makin diperbaiki, pihak operator juga sudah banyak mengembangkan telepon pintar yang digunakan dalam mempermudah sarana komunikasi dengan HP yang canggih saat ini. Aplikasi juga banyak di update sesuai apa yang diinginkan pelanggan yang tentunyaakan mempermudah segala sesuatu saat belajar.

Dalam melakukan pembelajaran secara daring, kreatifitas guru dalam meciptakan inovasi-inovasi baru kaitannya dengan pengggunaan strategi, 
2021 | Khoriah, S.N., Rizkia, N.M., Awwaliyah, A.F., Ramadhani, A.D., Umam, A.M., Mubarok, H., Pembelajaran Sekolah Indonesia Luar Negeri di Tengah Pandemi Covid-19 di Sekolah Indonesia Kuala Lumpur (SIKL) dan Sekolah Indonesia Den Haag (SIDH)

metode, media dan perangkat pembelajaran lainnya sangat dibutuhkan untuk mengoptimalkan pembelajaran secara efektif dan efisien. Guru harus menguasai berbagai multimedia untuk diterapkan dalam proses pembelajaran supaya peserta didik mampu mempelajari dan memahami pembelajaran dengan baik.

\section{Pembelajaran Sekolah Indonesia Luar Negeri Di Tengah Pandemi Covid-19 Di Sekolah Indonesia Kuala Lumpur (SIKL)}

Sekolah indonesia kuala lumpur merupakan sekolah indonesia yang ada di malaysia. SIKL sekarang genap berusia 50. Diresmikan pada tanggal 10 Juli 1969. SIKL sekarang menggunakan kurikulum nasional/kurikulum K13. Sejarah berdirinya SIKL diprakarsai pada tahun 1967 oleh Atase Pendidikan dan Kebudayaan Kedutaan Bear Republik Indonesia (KBRI) Kuala Lumpur, Bapak Bambang Sumadio yang kemudian dilanjutkan oleh Atase selanjutnya, Bapak Muhammad Alwi Oemry sekaligus ditugas sebagai kepala sekolah SIKL yang pertama oleh Duta Besar RI, Bapak Mayjen H. A. Thalib. SIKL diresmikan pada tanggal 10 Juli 1969 dengan pengguntingan pita oleh Ibu Nurdjanah Thalib, istri Duta Besar LBBP yang dihadiri oleh Menteri Pelajaran
Malaysia, Yang Mulia Dato' Haji Abdul Rachman Yakob. Secara resmi pendirian SIKL telah ditetapkan berdasarkan Surat Keputusan Menteri Pendidikan dan Kebudayaan Nomor 05/1971 tanggal 7 Januari 1971.

SIKL sekarang menggunakan kurikulum nasional/kurikulum K13. Ada beberapa program unggulan yang dimiliki SIKL, diantaranya RPP digital, kelas tanpa piket, kantin kejujuran, SIKL Channel TV, kurikulum yang diselaraskan, SIKL expression stage, belajar dirumah "ramah anak", teacher media digital dan library explorace. Tantangan guru di SIKL yaitu bagaimana untuk menjaga rasa nasionalisme di negara lain, serta di SIKL juga ada beberapa ekstrakurikuler yang mana alatalatnya hanya ada di Indonesia, ini menjadi sebuah tantagan bagi guru. Oleh karenanya guru dituntut memiliki kreatifitas dan inovasi yang tinggi sehingga mampu membuat alat-alat yang dibutuhkan sendiri.

Penyebaran virus corona ini tidak hanya berdampak pada dunia ekonomi tetapi juga pada dunia pendidikan, membuat pemerintah dan lembaga terkait harus menghadirkan alternatif proses pendidikan bagi peserta didik maupun mahasiswa yang tidak bisa melaksanakan proses pendidikan pada lembaga 
2021 | Khoriah, S.N., Rizkia, N.M., Awwaliyah, A.F., Ramadhani, A.D., Umam, A.M., Mubarok, H., Pembelajaran Sekolah Indonesia Luar Negeri di Tengah Pandemi Covid-19 di Sekolah Indonesia Kuala Lumpur (SIKL) dan Sekolah Indonesia Den Haag (SIDH)

pendidikan. Pemerintah menghimbau untuk bekerja, belajar, dan beribadah dari rumah untuk menekan angka pasien yang terpapar Covid-19. Sehingga kegiatan belajar dilakukan secara daring (online) dan berlangsung dengan sistem PJJ (Pembelajaran Jarak Jauh).

Menteri Pendidikan dan Kebudayaan Republik Indonesia mengeluarkan surat edaran nomor 4 Tahun 2020 tentang Pelaksanaan Kebijakan dalam Masa Darurat Penyebaran Coronavirus Disease (Covid19) poin ke 2 yaitu proses belajar dari rumah dilaksanakan dengan ketentuan sebagai berikut:

a. Belajar dari rumah melalui pembelajaran daring/jarak jauh dilaksanakan untuk memberikan pengalaman belajar yang bermakna bagi siswa, tanpa terbeban tuntutan menuntaskan sebuah capaian kurikulum untuk kenaikan kelas atau kelulusan.

b. Belajar dari rumah dapat difokuskan pada pendidikan kecakapan hidup antara lain mengenai pandemi Covid-19.

c. Aktivitas dan tugas pembelajaran belajar dari rumah dapat bervariasi antar siswa, sesuai minat dan kondisi masing-masing, termasuk mempertimbangkan kesenjangan akses dan fasilitas belajar di rumah .

d. Bukti atau produk aktivitas belajar dari rumah diberi umpan balik yang bersifat Kualitatif dan berguna bagi guru, tanpa diharuskan memberi skor/kuantitatif.

Pembelajaran online atau daring adalah sistem belajar yang terbuka dan tersebar dengan menggunakan perangkat pedagogi (alat bantu Pendidikan), yang dimungkinkan melalui internet dan teknologi berbasis jaringan untuk memfasilitasi pembentukan proses belajar dan pengetahuan melalui aksi dan interaksi yang berarti. Pembelajaran daring merupakan bagian pendidikan jarak jauh, yang didefinisikan sebagai penyampaian instruksi formal di mana waktu dan lokasi geografis memisahkan pelajar dengan pendidiknya. Pembelajaran daring dikembangkan sebagai media pembelajaran yang dapat menghubungkan secara daring antara pendidik dan pelajar dalam sebuah ruang kelas maya tanpa harus dalam satu ruangan secara fisik.

Pembelajaran yang dilakukan secara daring tetap melaksanakan KBM seperti biasanya, namun yang membedakan adalah pada ruang-ruang terpisah yaitu di rumah masing-masing. Didalam melakukan proses pembelajaran 
2021 | Khoriah, S.N., Rizkia, N.M., Awwaliyah, A.F., Ramadhani, A.D., Umam, A.M., Mubarok, H., Pembelajaran Sekolah Indonesia Luar Negeri di Tengah Pandemi Covid-19 di Sekolah Indonesia Kuala Lumpur (SIKL) dan Sekolah Indonesia Den Haag (SIDH)

secara daring tentunya terdapat beberapa hambatan. Adapun beberapa hambatan tersebut adalah masih ada beberapa peserta didik yang belum mempunyai Hand Phone sebagai alat komunikasi pada pembelajaran, rendahnya penguasaan tekonolgi dan informasi, tidak semua peserta didik hadir ketika KBM berlangsung, keterbatasan kuota dan jaringan internet yang kurang mendukung, serta hambatan-hambatan lainnya.

Pembelajaran secara daring dapat dilakukan dengan memanfaatkan elearning. E-learning adalah teknologi informasi dan komunikasi untuk mengaktifkan siswa belajar kapanpun dan dimanapun. E-learning memiliki dua tipe yaitu: Pertama, proses pembelajaran pada saat yang sama antara pendidik dan peserta didik. Aplikasi yang digunakan yaitu; WhatsApp Group, Zoom Cloud Meeting, Google Classroom, Google Meet. Kedua, proses pembelajaran tidak pada waktu bersamaan. Peserta didik dapat mengambil waktu berbeda dengan pendidik. Aplikasi yang digunakan yaitu; Ruang Guru, Zenius, dan Kelas Pintar. Namun Dalam proses pembelajaran daring yang dilakukan siswa tidak lepas dari pengawasan orang tua dan guru. Untuk mendapatkan proses pembelajaran yang efektif dan menyenangkan diperlukan kerjasama guru dan orang tua dengan proses pembelajaran yang bervariatif.

Proses belajar berbasis e-learning membutuhkan sarana dan prasarana yang mendukung diantaranya adalah Smartphone, Komputer atau Laptop, Aplikasi, serta Jaringan yang digunakan sebagai media dalam berlangsungnya pembelajaran. Namun tidak semua siswa dapat menjalani secara konsisten pembelajaran daring dikarenakan keterbatasan. Misalnya, tidak memiliki smartphone, rendahnya pemahaman media digital, keterbatasan kuota internet maupun sinyal.

\section{Pembelajaran melalui Google} Classroom, Zoom Cloud Meeting, dan Google Meet di sekolah dasar dilakukan pada siswa kelas tinggi karena pada usia tersebut siswa sudah siap menerima perkembangan zaman melalui teknologi yang ada. Hal yang harus diperhatikan adalah guru memberikan pemahaman kepada wali murid agar tidak terjadi kesalahpahaman dalam penggunaanya. Memberikan pelatihan kepada siswa tentang penggunaan aplikasi tersebut sebagai tahap pengenalan fungsi dan manfaat perangkat lunak tersebut. Pembelajaran jarak jauh dengan penerapan metode pemberian tugas secara daring melalui WhatsApp Group 
2021 | Khoriah, S.N., Rizkia, N.M., Awwaliyah, A.F., Ramadhani, A.D., Umam, A.M., Mubarok, H., Pembelajaran Sekolah Indonesia Luar Negeri di Tengah Pandemi Covid-19 di Sekolah Indonesia Kuala Lumpur (SIKL) dan Sekolah Indonesia Den Haag (SIDH)

dianggap efektif. Karena siswa di kelas rendah masih memerlukan bimbingan secara ekstra, selain itu jika menggunakan aplikasi lainnya siswa tersebut belum paham dan tidak menutup kemungkinan para orang tua juga belum begitu paham cara mengaplikasikannya. Dengan menggunakan aplikasi WhatsApp bisa melakukan video call secara langsung dengan siswa dan bisa mengirimkan video pembelajaran, materi dan tugas kepada siswa.

Beberapa sekolah yang berada di daerah pedalaman dan banyak siswa yang terbatas mengakses internet tentu belum menyelenggarakan pembelajaran secara daring. Di sini guru harus berkreatifitas untuk memanfaatkan media belajar alternatif selama peserta didik belajar di rumah. Mereka dapat menggunakan sumber belajar yang ada yaitu buku siswa sesuai dengan tematema yang diajarkan sesuai dengan jadwal yang dibuat sebelumnya.

Kemendikbud memberikan kebebasan pada setiap sekolah untuk memilih platform belajar daring. Untuk mendorong adanya proses berbagi pengetahuan, kemendikbud menyediakan platform belajar daring gratis bernama "Rumah Belajar" yang menyediakan bahan mengajar dan fitur komunikasi bagi penggunanya dan sebuah platform untuk berbagi antar guru bernama "Program Guru Berbagi" berbagi Rencana Pelaksanaan Pembelajaran (RPP) dengan guru-guru. Untuk daerah yang koneksi internetnya kurang baik, pemerintah bekerjasama dengan TVRI untuk menyampaikan materi belajar yang ada di dalam program Belajar di Rumah untuk beberapa bulan.

Perpaduan belajar offline dan online adalah suatu keputusan yang demokratis untuk menjembatani derasnya arus penyebaran sumber belajar elektronik (e-learning) dan kesulitan melepaskan diri dari pemanfaatan sumber-sumber belajar yang digunakan di ruang kelas. Bagaimanapun canggihnya teknologi yang digunakan belum mampu menggantikan pelaksanaan pembelajaran tatap muka. Karena metode interaksi tatap muka konvensional masih lebih efektif dibandingkan pembelajaran online atau e-learning. Selain itu keterbatasan dalam aksesibilitas internet, perangkat keras, dan perangkat lunak, serta biaya sering menjadi hambatan dalam memaksimalkan sumber-sumber belajar online.

Pada pembelajaran yang
dilaksanakan dirumah pada masa
pandemi ini, guru dan siswa tentunya
akan merasa lebih dekat dengan adanya


2021 | Khoriah, S.N., Rizkia, N.M., Awwaliyah, A.F., Ramadhani, A.D., Umam, A.M., Mubarok, H., Pembelajaran Sekolah Indonesia Luar Negeri di Tengah Pandemi Covid-19 di Sekolah Indonesia Kuala Lumpur (SIKL) dan Sekolah Indonesia Den Haag (SIDH)

informasi dan teknologi. Maka dari itu, guru maupun siswa harus mampu mengoptimalkan dalam penggunaan teknologi tersebut. Meskipun siswa belajar di rumah dengan dampingan orang tua, Guru di SIKL tetap memberikan pendampingan yang tidak kurang. Dengan menyiapkan banyak instrumen agar siswa tetap bisa melakukan dan meningkatkan karakter mereka walaupun belajar di rumah.

Pembelajaran yang dilakukan SIKL di rumah masing-masing dimulai sejak Maret 2020, dengan adanya pembelajaran secara online, maka guru harus berusaha menerapkan multimedia bagi pembelajaran tersebut. Pada pembelajaran yang dilakukan secara online tidak terjadi kendala yang cukup berat pada jaringan internet karena letak SIKL yang terletak strategis di tengah kota, sehingga terdapat jaringan internet yang kuat. Rencana pelaksanaan pembelajaran (RPP) yang digunakan guru dalam melaksanakan proses pembelajaran tidak lagi secara manual tetapi sudah terdapat di aplikasi atau RPP digital. Aplikasi RPP digital membantu memudahkan guru-guru dalam mempersiapkan pembelajaran di masa pandemi.

Kreatifitas guru sangat dibutuhkan dalam pembelajaran di rumah saja dengan menyeimbangkan antara pembelajaran secara online dan offline serta tidak menginginkan siswa depresi ketika belajar di rumah tetapi tetap mencapai standar kurikulum.

Untuk mencegah penularan covid-19, berdasarkan himbauan kemendikbud dan kerajaan Malaysia, maka seluruh siswa SIKL belajar di rumah. Agar siswa tetap mendapatkan layanan pendidikan dengan belajar di rumah, maka kepala sekolah, Dr. Encik Abdulhajar, MM mendorong dan memberikan keleluasaan kepada para guru untuk memberikan pembelajaran dari rumah dengan menggunakan aplikasi pembelajaran jarak jauh yang sesuai dengan keadaan siswa. Sekarang ini, banyak aplikasi yang dapat digunakan guru sebagai sarana pembelajaran jarak jauh seperti, rumah belajar Kemendikbud, ruang guru, google classroom, moodle, edmodo, kahoot, quizizz, skype, zoom, kelase, dan lain sebagainya. Salah satu contoh penggunaan virtual classroom yang digunakan guru dalam melaksanakan pembelajaran dari rumah yaitu dengan menggunakan ZOOM Clouds Meetings sebagai sarana untuk bertatap muka secara virtual dengan memberikan pelajaran kepada para siswa dan untuk melatih pemahaman siswa atas pelajaran 
2021 | Khoriah, S.N., Rizkia, N.M., Awwaliyah, A.F., Ramadhani, A.D., Umam, A.M., Mubarok, H., Pembelajaran Sekolah Indonesia Luar Negeri di Tengah Pandemi Covid-19 di Sekolah Indonesia Kuala Lumpur (SIKL) dan Sekolah Indonesia Den Haag (SIDH)

yang dilakukan secara virtual tersebut, guru menggunakan Quizizz web tool untuk membuat permainan kuis interaktif.

Dengan penggunaan berbagai macam media pembelajaran tersebut meskipun secara online, para siswa sangat senang karena mendapatkan pengalaman baru dengan virtual classroom dengan dampingan orang tua di rumah. Guru-guru pun dapat meningkatkan kreatifitas dalam melaksanakan proses pembelajaran secara online dengan menarik dan menyenangkan, sehingga proses pembelajaran yang dilakukan siswa di rumah masing-masing tidak merasa bosan.

Sekolah Indonesia Kuala Lumpur membuat sebuah program pembelajaran jarak jauh melalui online video conference yakni SIKL Inspiration class yang digagas oleh guru Bahasa Inggris SMA kelas X-XI IPA dan IPS yaitu Lina Hasna, S.Pd. untuk memberikan pengalaman baru kepada siswa agar terinspirasi dan termotivasi untuk tetap semangat belajar di rumah dari quest speaker yang diundang. Selain pembelajaran mengenai motivasi dan Bahasa Inggris, SIKL inspiration class juga mengajak siswa untuk memahami cultural understanding dengan tujuan menambah wawasan siswa-siswi di SIKL.

Sekolah Indonesia Kuala Lumpur mengeluarkan kebijakan kaitannya dengan proses belajar dari rumah dengan tujuan supaya anak tidak merasa bosan dengan menggalakkan "Belajar dari rumah ramah anak" . Adapun kebijakankebiajakan yang dikeluarkan antara lain sebagai berikut:

1. Siswa yang dikategorikan beresiko tinggi (high risk) tidak diperkenankan belajar di sekolah melainkan mengikuti proses belajar di rumah.

2. Menyeimbangkan rasio kegiatan kurikuler dan ko kurikuler (60:40\%).

3. Tidak terlalu fokus pada pencapaian target kurikulum.

4. Porsi belajar di rumah secara offline (unsynchronous) lebih banyak dari pada secara online (synchronous).

5. Platform belajar di rumah menggunakan Google Classroom sebagai kelas utama.

6. Guru mempersiapkan media video pembelajaran untuk proses belajar di rumah.

7. Adanya rubik laporan harian belajar di rumah (Google form).

Di masa pandemi covid-19 menuju normal baru, meskipun tetap belajar dari rumah, sekolah Indonesia Kuala Lumpur 
2021 | Khoriah, S.N., Rizkia, N.M., Awwaliyah, A.F., Ramadhani, A.D., Umam, A.M., Mubarok, H., Pembelajaran Sekolah Indonesia Luar Negeri di Tengah Pandemi Covid-19 di Sekolah Indonesia Kuala Lumpur (SIKL) dan Sekolah Indonesia Den Haag (SIDH)

tetap menyelenggarakan perlombaan secara online dalam rangka menyambut Hari Kemerdekaan Indonesia atau hari ulang tahun (HUT) Indonesia yang ke-75 yang dapat diikuti guru maupun siswa, mulai dari TK, SD, SMP, dan SMA. Adapun lomba- lomba yang diadakan di masa pandemic covid-19 dengan tetap di rumah saja adalah lomba vlog guru SIKL, lomba vlog siswa SIKL, lomba desain poster, lomba fashion show TK, lomba pidato tingkat SD dan SMA, lomba menyanyi solo tingkat SD, SMP, dan SMA, lomba storytelling SD dan SMP, lomba cipta puisi dan lain- lain.

Pada pembelajaran di tengah pandemi covid-19, Sekolah Indonesia Kuala Lumpur mengadakan collaborative learning dengan sekolah Republik Indonesia Tokyo yang dilakukan secara daring. Kegiatan tersebut dilakukan pada pembelajaran Bahasa Indonesia di kelas V SD Sekolah Indonesia Kuala Lumpur dan kelas V SD Sekolah Republik Indonesia Tokyo. Dengan adanya kegiatan tersebut, siswa kedua sekolah dapat bertukar cerita dan informasi tentang pengalam semasa self quatantine di Negara masing- masing. Tidak hanya bertukar cerita dan informasi, mereka juga bertukar tips cara mengatasi kebosanan saat belajar di rumah.

\section{Pembelajaran Sekolah Indonesia Luar Negeri Di Tengah Pandemi Covid-19 Di Sekolah Indonesia Den Haag (SIDH)}

Sekolah Indonesia Den Haag merupakan sekolah Indonesia yang berada di Belanda. Sekolah Indonesia Den Haag merupakan sekolah berstatus swasta dengan berbantuan (bantuan pemerintah), sedangkan status sekolah tersebut di Belanda adalah sebagai sekolah asing. SIDH diselenggarakan dalam rangka memberikan pelayanan kepada masyarakat Indonesia yang berada di Belanda kaitannya dengan pendidikan yang bermutu, kompetitif, relevan, dan berstandar internasional, tetapi tetap mempertahankan kepribadian dan kebudayaan yang ada di Indonesia.

Pada hakikatnya lembaga pendidikan SIDH (Sekolah Indonesia Den Haag) di bawah naungan KBRI, bahasa pengantar resmi yang diterapkan dalam SIDH adalah Bahasa Inggris, dan kurikulum yang digunakan sama seperti kurikulum di Indonesia yaitu kurikulum 2013 (K13) dan menggunakan pembelajaran secara tematik. Yang membedakan antara sekolah di Indonesia dan SIDH adalah ketersediaan dan kelengkapan media penunjang praktik pembelajaran serta letak sekolah yang berada di dalam negeri dan luar negeri. 
2021 | Khoriah, S.N., Rizkia, N.M., Awwaliyah, A.F., Ramadhani, A.D., Umam, A.M., Mubarok, H., Pembelajaran Sekolah Indonesia Luar Negeri di Tengah Pandemi Covid-19 di Sekolah Indonesia Kuala Lumpur (SIKL) dan Sekolah Indonesia Den Haag (SIDH)

Karena adanya pandemi yang mewabah di dunia, salah satunya juga terjadi di Negara Belanda, hal tersebut membawa dampak besar bagi berbagai bidang kehidupan, salah satunya yaitu dalam bidang pendidikan. Proses pembelajaran yang biasanya dilakukan di sekolah dipindahkan di rumah masingmasing. SIDH melakukan pembelajaran menurut aturan dari pemerintah yaitu melalui pembelajaran daring. Pembelajaran daring dilakukan sejak bulan Juni 2020 tersebut di mulai dari jam 9 pagi sampai jam 2 siang, sedangkan untuk ujian dilakukan di goggle form untuk sekolah regular. Meskipun pembelajaran tersebut berlangsung daring, namun mereka masih tetap melakukan pembelajaran seperti biasa dengan bantuan dan bimbingan dari orang tua. Mengenai kurikulum yang ada di SDIH mengunakan kurikulum seperti yang ada di Indonesia yaitu kurikulum 2013 dan menggunakan buku BSE Elektronik, antara kurikulum untuk kelas Reguler dengan kurikulum kelas PJJ ada perbedaan yaitu dalam bobot jam belajarnya.

Sarana dan prasarana pembelajaran di rumahakan disesuaikan dengan bahan pengajaran dan jadwal belajar yang akan diberikan dari staf pengajar SIDH. Orang tua dapat menggunakan seluruh sarana, akses dan referensi yang ada sebagai bahan pengajaran. Selain itu untuk memperlancar arahan dan bimbingan anak selama belajar di rumah, maka SIDH memfasilitasi orang tua dengan layanan konsultasi online, baik dengan sarana "Facebook" , "Skype” maupun mailing-list sehingga orang tua juga dapat berkomunikasi tidak hanya dengan staff pengajar SIDH tetapi juga dengan orang tua lainnya. Untuk itu diharapkan orang tua atau siswa memiliki fasilitas komputer dan koneksi internet di rumah. selain komputer telepon pintar juga sangat diperlukan untuk menunjang

Bagian ini menyajikan pembelajaran karena percakapan antara guru dengan siswa akan lebih intens jika di laksanakan di aplikasi WhatsApp chat. Di SIDH memiliki 2 kelas yaitu kelas kecil dan kelas besar. Kelas kecil meliputi kelas 1 sampai kelas 4 sedangkan kelas besar meliputi kelas 5 dan 6. pembagian kelas kecil ataupun kelas besar pada dasarnya sama dengan yang dilakukan sekolah di Indonesia pada guru memberlakukan sistem kelas kecil atau besarguru memberlakukan sistem kelas kecil atau besar karena dirasa efektif untuk agar lebih mudah untuk mengelompokkan siswa baik pada 
2021 | Khoriah, S.N., Rizkia, N.M., Awwaliyah, A.F., Ramadhani, A.D., Umam, A.M., Mubarok, H., Pembelajaran Sekolah Indonesia Luar Negeri di Tengah Pandemi Covid-19 di Sekolah Indonesia Kuala Lumpur (SIKL) dan Sekolah Indonesia Den Haag (SIDH)

saat tes maupun hal lainnya. Pada saat dilakukan ujian, test atau penilaian disekolah, sarana dan prasarana standar disediakan oleh SIN. Ditambah dengan beberapa kebutuhan fasilitas khusus seperti pemanfaatan ICT.

Di masa pembelajaran daring ini, guru sebagai pendidik yang berperan penting dalam berlangsungnya proses pembelajaran diharuskan untuk menguasai berbagai macam perkembangan teknologi untuk menjalankan misi mengajar dengan berjarak jauh. Guru harus bisa menguasai seluruh aplikasi teknologi dari HP maupun karena Penguasaan teknologi tersebut bertujuan agar guru mampu menerapkan pembelajaran secara daring dengan efektif dan tidak menemukan masalah yang cukup berat.

\section{KESIMPULAN}

Pembelajaran dengan menggunakan sistem daring diterapkan dalam Sekolah Indonesia Kuala Lumpur (SIKL) dan Sekolah Indonesia Den Haag (SIDH) dalam masa pandemi Wabah Covid-19 ini. Meski dalam kondisi yang serba terbatas karena pandemi COVID19 tidak menjadi penghalang untuk melakukan pembelajaran secara daring. Beberapa hal yang menjadi hambatan adalah orang tua harus menambah waktu untuk mendampingi anak-anak. Sedangkan dari segi guru, guru menjadi melek teknologi dan dituntut untuk belajar banyak hal kususnya pembelajaran berbasis daring. Sistem pembelajaran daring ini dapat dijadikan sebagai model dalam melakukan pembelajaran selanjutnya.

Di masa pembelajaran daring ini, guru sebagai pendidik yang berperan penting dalam berlangsungnya proses pembelajaran diharuskan untuk menguasai berbagai macam perkembangan teknologi untuk menjalankan misi mengajar dengan berjarak jauh. Penguasaan teknologi tersebut bertujuan agar guru mampu menerapkan pembelajaran secara daring dengan efektif dan tidak menemukan masalah yang cukup berat. Simpulan dapat bersifat generalisasi temuan sesuai permasalahan penelitian, dapat pula berupa rekomendatif untuk langkah selanjutnya.

\section{DAFTAR PUSTAKA}

Aji Fatma Dewi, Wahyu. (2020). Dampak Covid-19 Terhadap Implementasi Pembelajaran Daring Di Sekolah Dasar. Jurnal Ilmu Pendidikan, Vol. 2, No. 1.

Atsani, Muhammad Zainudin. (2020). Transformasi Media 
2021 | Khoriah, S.N., Rizkia, N.M., Awwaliyah, A.F., Ramadhani, A.D., Umam, A.M., Mubarok, H., Pembelajaran Sekolah Indonesia Luar Negeri di Tengah Pandemi Covid-19 di Sekolah Indonesia Kuala Lumpur (SIKL) dan Sekolah Indonesia Den Haag (SIDH)

Pembelajaran Pada Masa

Pandemi Covid-19. Jurnal Studi

Islam, Vol. 1, No. 1.

Fitriana, D. (2018). Peran Media Elearning Dalam Pembelajaran Untuk Mengoptimalkan Kemampuan Literasi Matematika dan Norma Sosiomatematik. Program Studi Pendidikan Guru Sekolah Dasar Program Studi Pendidikan Matematika Universitas Muria Kudus, (0291).

Hakim. (2016). Efektifitas Penggunaan E-learning Moodle, Google Classroom Dan Edmodo. IStatement.

Nataliani, Dessy dan Gunar Yadi. "KKL Virtual International dengan Sekolah Indonesia Den Haag". Hasil Wawancara Virtual: 19 Agustus 2020.

Purbayanto, Ari. (2016). Layanan Pendidikan Bagi Anak-anak Indonesia Di Malaysia. Kuala Lumpur.

Rosali, Ely Satiyasih. (2020). Aktivitas Pembelajaran Daring Pada Masa Pandemi Covid-19 Di Jurusan Pendidikan Geografi Universitas Siliwangi Tasikmalaya. Geography
Science Education Journal, Vol. 1, No. 1.

Sya'adah, Himatus dan Sulton Kamal. "KKL Virtual International dengan Sekolah Indonesia Kuala Lumpur". Hasil Wawancara Virtual: 18 Agustus 2020.

Sumanto, Y., \& Sadewo, Y. D. (2021). PELATIHAN PEMBUATAN VIDEO PEMBELAJARAN SEBAGAI MEDIA PEMBELAJARAN DARING DI SD NEGERI SOJOPURO DALAM MASA COVID19. Journal of Educational Learning and Innovation (ELIa), 1(1), 01-14. https://doi.org/10.46229/elia.v1i 1.237

Yaumi, Muhammad. (2018). Media Dan Teknologi Pembelajaran. Jakarta: Prenadamedia Group.

Zhafira, N. H., Ertika, Y., Chairiyaton, C. (2020). Persepsi Mahasiswa Terhadap Perkuliahan Daring Sebagai Sarana Pembelajaran. Jurnal Bisnis Dan Kajian Strategic Manajemen, 4 (1).

@ sekolahindonesiakualalumpur. (2020, 16 Maret). Virtual Learning Kelas 4 SD (Instagram Profile Post). Diakses melalui 
2021 | Khoriah, S.N., Rizkia, N.M., Awwaliyah, A.F., Ramadhani, A.D., Umam, A.M., Mubarok, H., Pembelajaran Sekolah Indonesia Luar Negeri di Tengah Pandemi Covid-19 di Sekolah Indonesia Kuala Lumpur (SIKL) dan Sekolah Indonesia Den Haag (SIDH)

https://www.instagram.com/p/C

$\underline{\text { ARmBjgifwc/?igshid }=6 \mathrm{mzbql} 32}$

peus

@ sekolahindonesiakualalumpur. (2020,

19 Maret). SIKL Inspiration

Class : Online Video Conference

(Instagram Profile Post). Diakses

melalui

https://www.instagram.com/p/C

$\underline{\text { ARno4Xjrd7/?igshid=1xitsprnu }}$

$\underline{0 \mathrm{q} 13}$

@ sekolahindonesiakualalumpur. (2020,

07 April). SIKL Collaborative
Learning with Sekolah Republik

Indonesia Tokyo (Instagram

Profile Post). Diakses melalui

https://www.instagram.com/p/C

$\underline{\text { ARlgpejBXi/?igshid=1nkz47dc3 }}$

cupe

@ sekolahindonesiakualalumpur. (2020,

09 Agustus). Kebijakan Belajar

Di Rumah "Ramah Anak"

(Instagram Profile Post). Diakses

melalui

https://www.instagram.com/p/C

DprrvnjNV1/?igshid=1ub5kqsk oytte 